\title{
Candida Utilis and Candida Lusitaniae Meningitis in an Infant with Extraventricular Drainage
}

\author{
Ekstraventriküler Drenajlı Bir Infantda Candida Utilis ve Candida Lusitaniae
} Menejiti

\author{
Fatma Mutlu Sariguzel ${ }^{1^{*}}$, Ayse Nedret $\mathrm{Koc}^{2}$, Mustafa Ozturk ${ }^{3}$ \\ ${ }^{1}$ Departments of Microbiology, Kayseri Training and Researb Hospital, Kayseri, Turkey \\ ${ }^{2}$ Departments of Microbiology Erciyes University, Medical School Kayseri, Turkey \\ ${ }^{3}$ Department of Pediatrics, Erciyes University, Medical School, Kayseri, Turkey
}

\begin{abstract}
The eight-month male infant was admitted to our hospital because of febrile convulsion and pre-diagnosis of meningitis. Hydrocephalus was observed shortly after the admission and extraventricular drainage was performed but then the patient had fever above $38^{\circ} \mathrm{C}$. Yeasts were detected in cerebrospinal fluid culture of the patient. These fungi were identified as Candida utilis and Candida lusitaniae. For these fungi, the minimal inhibitory concentrations of fluconazole and amphotericin B were 2 $\mu \mathrm{g} / \mathrm{ml}, 4 \mu \mathrm{g} / \mathrm{ml}$ and $0.75 \mu \mathrm{g} / \mathrm{ml}, 0.5 \mu \mathrm{g} / \mathrm{ml}$, respectively. The patient received antifungal treatment but on day 10 after the isolation of yeast, the patient died. The fungi were not detected in blood and cerebrospinal fluid culture of the postmortem of the patient. In conclusion, after performing extra ventricular drainage, fungi, especially $C$. Iusitaniae and $C$. utilis, should be thought as etiological agents of developing meningitis.
\end{abstract}

Key Words: Candida utilis, Candida Iusitaniae, extraventricular drainage, meningitis

\section{Introduction}

Candida spp. is the most common opportunistic fungal infection in human and causes central nervous system (CNS) infections (1). Candida spp. causes an infection with high level of mortality and morbidity in CNS. There are some risk factors for the development of fungus infection in CNS such as; immunosuppression diseases, broad spectrum antibiotic therapy or corticosteroid treatment, carrying intravascular catheters, having neurosurgery operations, insertion of cerebrospinal fluid (CSF) derivate systems and IV drug usage. Foreign devices as intravenous catheters implanted in a susceptible host are

\begin{abstract}
ÖZET
Sekiz aylık erkek hasta menejit ve febril konvulziyon ön tanısı ile hastanemize kabul edilmiştir. Hastanemize kabulünden kısa bir sure sonra hidrosefali gelişmiş ve hastaya ekstraventriküler drenaj yapılmıştır. Ancak işlemden sonra hastanın ateşi $38^{\circ} \mathrm{C}$ yükselmiştir. Hastanın beyin omurilik sıvısı kültüründe maya üremesi olmuştur. İzole edilen mayalar Candida utilis ve Candida lusitaniae olarak tanımlanmıştır. Suşların flukonazol ve amfoterisin B için minimal inhibisyon konsantrasyonları sırası ile 2 $\mu \mathrm{g} / \mathrm{ml}, \quad 4 \mu \mathrm{g} / \mathrm{ml}$ and $0.75 \mu \mathrm{g} / \mathrm{ml}, 0.5 \mu \mathrm{g} / \mathrm{ml}$ olarak saptanmıştır. Hasta antifungal tedavi almış fakat mayanın izolasyonundan sonra 10 . günde kaybedilmiştir. Postmortem beyin omurilik sıvısı ve kan kültüründe maya saptanmamıştır. Sonuç olarak, ekstraventriküler drenaj uygulandıktan sonra mantarlar, özellikle C. lusitaniae ve $C$. utilis, meydana gelen menejitlerin etiyolojik etkeni olarak düşünülmelidir.
\end{abstract}

Anahtar Kelimeler: Candida utilis, Candida lusitaniae, ekstraventriküler drenaj, menejit

known to act as a nidus for the infectious agent (2). C. albicans is an agent in most cases. While C. lusitaniae is reported to be the cause of the catheter-associated meningitis (3), C. utilis and C. lusitaniae together have not been reported to cause the meningitis in literature. Here, we report a catheter-associated meningitis case caused by $C$. utilis and $C$. lusitaniae together.

\section{Case Report}

An eight-month male infant was admitted to our hospital because of febrile convulsion and with the pre-diagnosis of meningitis. The weight of patient was 6500 gr. His history revealed that he 
was born at term by normal vaginal delivery to a primigravid mother. In general physical examination there was not skin eruption in the body and the anterior fontanelle was bulging. Body tempareture was $38{ }^{\circ} \mathrm{C}$. The laboratory data on admission was as follows; platelet 104 cells $/ \mathrm{mm}^{3}$, hemoglobin $9.7 \mathrm{~g} / \mathrm{dL}$, white blood cell count $6.05 / \mathrm{mm}^{3}$, the serum glucose level $99 \mathrm{mg} / \mathrm{dL}$, serum protein $5.3 \mathrm{~g} / \mathrm{dL}$, the CSF glucose level $39 \mathrm{mg} / \mathrm{dL}$, the CSF protein level $1.153 \mathrm{~g} / \mathrm{dL}$ and many polymorphonuclear leukocytes (PMNs) were observed in the CSF by the Gram staining. CSF initial cultures was negative. HSV PCR test was negative in CSF. We observed widespread hypo dens area and doubtful infract area in cranial computed tomography scan of the patient. Treatments with anticonvulsion, broad-spectrum antibiotic and corticosteroid were started. On the second day of admission to hospital, the patient was admitted to intensive care unit because of the respiration problem. Mechanical ventilation was started. Following admission to intensive care unit, hydrocephalus was observed in the patient and extraventricular drainage was attached. Five days after admission, the patient had high fever $\left(39.4{ }^{\circ} \mathrm{C}\right)$. The laboratory data was as follows; white blood cell count was $11.63 / \mathrm{mm}^{3}$, the serum glucose level $103 \mathrm{mg} / \mathrm{dL}$, serum protein $5.1 \mathrm{~g} / \mathrm{dL}$, the CSF glucose level $61 \mathrm{mg} / \mathrm{dL}$, the CSF protein level 4.3 $\mathrm{g} / \mathrm{dL}$, Many PMNs and lymphocytes were observed in the CSF by the Gram staining. Fungi were isolated from CSF culture of the patient. These fungi were identified as $C$. utilis and $C$. lusitaniae according to microscopic and macroscopic morphology, a germ tube test, hydrolysis of urea and carbonhydrate assimilation test by API AUX C 20 (bioMérieux, Marcy-l'Etoile

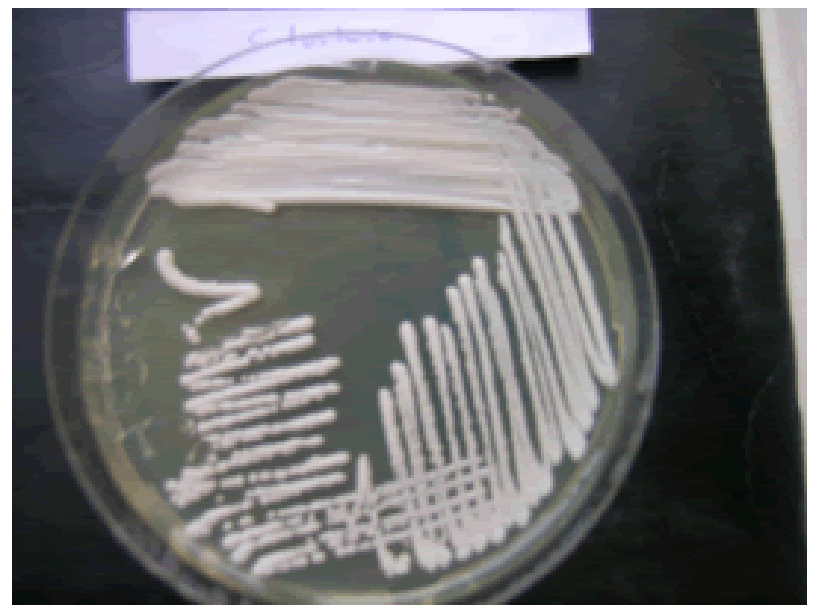

Fig. 1. Colonies of the C. lusitaniae strain on sabauroud dextrose agar.
/France). Both yeast were isolated from the same sample. Antifungal treatment (fluconazole $60 \mathrm{mg}$ / per day) was started on the patient. The patient's fever fell down to $37^{\circ} \mathrm{C}$. On the tenth day of the antifungal treatment, the patient died because of respiratory problem. The fungi were not isolated from blood and cerebrospinal fluid culture of the postmortem of the patient.

Mycological Examination: Colonies of the $C$. lusitaniae strain on sabauroud dextrose agar were bright and white colored (Figure 1). The germ tube test and hydrolysis of urea were negative. Cultures on cornmeal agar were examined for pseudohyphea and blastoconidia (Figure 2).

Colonies of the $C$. utilis strain on sabaroud dextrose agar were smooth and creamy colored (Figure 3). Hydrolysis of urea and germ tube test was negative. On cornmeal agar, they produced typically branched chains of cylindrical blastoconidia (Figure 4). The minimal inhibitory concentrations $\left(\mathrm{MIC}_{\mathrm{s}}\right.$ ) were determined by E-test method. For the $C$. lusitaniae and $C$. utilis strains, $\mathrm{MIC}_{\mathrm{s}}$ of fluconazole and amphotericin B (AMB) were $2 \mu \mathrm{g} / \mathrm{ml}, 4 \mu \mathrm{g} / \mathrm{ml}$ and $0.75 \mu \mathrm{g} / \mathrm{ml}, 0.5$ $\mu \mathrm{g} / \mathrm{ml}$, respectively.

\section{Discussion}

Candida species were the important cause of infectious meningitis in neurosurgical patient. C. albicans is the species of Candida most frequently involved (1). Less frequently, other species are responsible for meningitis, e.g. C. glabrata, $C$. tropicalis or C. lusitaniae $(2,3)$.

C. lusitaniae is originally isolated from the gastrointestinal tracts of warm-blooded animals and has recently been found to colonize rarely in

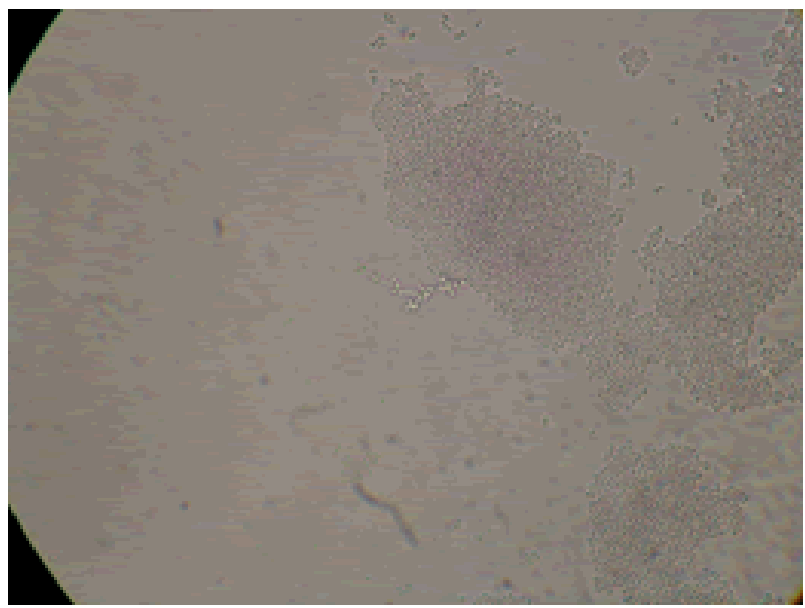

Fig. 2. Pseudohyphea and blastoconidia of C. lusitaniae on cornmeal agar. Magnification, X200. 


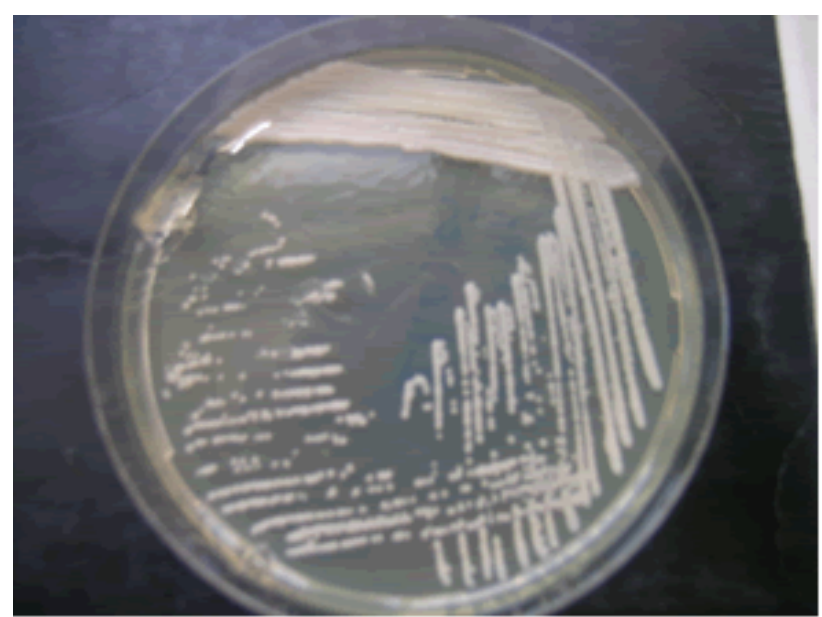

Fig. 3. Colonies of the C. utilis strain on sabauroud dextrose agar.

the gastrointestinal, respiratory and urinary tracts and skin of hospitalized patients (1). C. lusitaniae is opportunistic pathogen in human. C. lusitaniae infections make up $1 \%$ of nosocomial candida infections. The first case of the infection in men was described in 1979. Before 1990, only 28 fungemia due to $C$. lusitaniae had been reported suggesting that this Candida spp. was indeed rarely encountered as a human pathogen (4). More recently, $C$. Iusitaniae has been recovered from a variety of human clinical specimens such as cerebrospinal fluid $(5,6)$. Little is known about the risk factors for $C$. lusitaniae colonization and infection. Blinkhorn et al. (7) reported that most of the identified cases were immunocompromised patients with an underlying malignancy in the presence of prolonged broad spectrum antibiotics, prolonged hospitalization, intravascular catheters and cytotoxic or corticosteroid drugs. Many author reported cases of $C$. lusitaniae sepsis and meningitis in a premature infant and adult $(3,6)$. The initial resistance or the rapid development of resistance to amphoterisin B as determined by invitro susceptibility testing and by clinical failure of AMB therapy seems to be a hallmark of $C$. lusitaniae infection. However, several studies have reported $C$. lusitaniae infections that were susceptible to AMB (5-7). Peyron et al. (8) suggested to the $E$ test as the most sensitive and reliable means of detecting AMB resistance. Kollia et al. (9) reported MIC range of antifungal agents with the method of $\mathrm{E}$ test against $12 \mathrm{C}$. lusitaniae strains and the MIC range of $\mathrm{AMB}$ and fluconazole were 0.01-0.125, 0.75->64, respectively. Blinkhorn et al. (7) reported MIC for AMB of $2 C$. lusitaniae strains isolated in blood and for the C. lusitaniae strain isolated from their

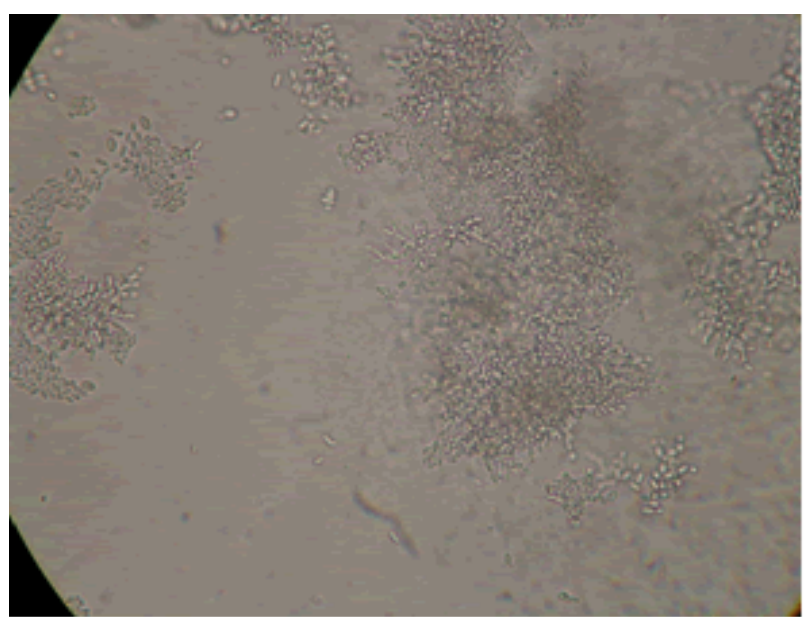

Fig. 4. Branched chains of cylindrical blastoconidia on cornmeal agar. Magnification, X200.

patients, the MIC of AMB was $0.39 \mu \mathrm{g} / \mathrm{ml}$. Leggiadro \& Collins reported a case of meningitis due to $C$. Insitaniae from postneurosurgical operation (craniotomy) in a 2 year old infant and for the $C$. Iusitaniae strain isolated from their patient, the MIC of AMB was $0.2 \mu \mathrm{g} / \mathrm{ml}(5)$. For the $C$. Iusitaniae strain isolated from our patient, the MIC of AMB and fluconazole were $0.75 \mu \mathrm{g} /$ $\mathrm{ml}$ and $2 \mu \mathrm{g} / \mathrm{ml}$, respectively. This fungus was found to be susceptible to both drugs

C. utilis is industrially important yeast, as it is capable of several useful nonethanolic fermentation reactions that result in the production of various organics, such as acetaldehyde. As a pathogen, C. utilis has been reported as a rare agent of fungemia (2). It is isolated very rarely from superficial clinical specimens. Its presence in the digestive tract of hospitalized patients is rare (10). Alsina et al. (2) reported catheter associated fungemia causing $C$. utilis in a patient with AIDS and the MIC of AMB was $0.52 \mu \mathrm{g} / \mathrm{ml}$. For the C. utilis strain isolated from our patient, the MIC s of AMB and fluconazole were $0.5 \mu \mathrm{g} / \mathrm{ml}$ and $4 \mu \mathrm{g} / \mathrm{ml}$, respectively. This strain was found to be susceptible to both drugs.

As a result, Candida utilis and Candida lusitaniae together that are rarely isolated can cause of meningitis in children with extraventricular drainage and taken broad spectrum antibiotic therapy and corticosteroid treatment.

Acknowledgments: The authors declare that there are no financial conflicts of interest.

\section{References}

1. Segal E, Elad D. Candidiasis. In: Merz, W.G. \& Hay, R.J. (eds) Topley\&Wilson's Microbiology \& 
Microbial Infections: Medical Mycology. Hodder Arnold ASM pres, 2005: 579-623.

2. Alsina A, Mason M, Uphoff RA, Riggsby WS, Becker JM, Murphy D. Catheter-associated Candida utilis fungemia in a patient with acquired immunodeficiency syndrome: species verification with a molecular probe. J Clin Microbiol 1988; 26(4): 621-624.

3. Sarma PS, Durairaj P, Padhye AA. Candida lusitaniae causing fatal meningitis. Postgrad Med J 1993; 69(817): 878-880.

4. Krcmery V, Barnes AJ. Non-albicans Candida spp. causing fungaemia: pathogenicity and antifungal resistance. J Hosp Infect 2002; 50(4): 243-260.

5. Leggiadro RJ, Collins T. Postneurosurgical Candida lusitaniae meningitis. Pediatr Infect Dis J 1988; 7(5): 368-369.
6. Sanchez PJ, Cooper BH. Candida lusitaniae sepsis and meningitis in a neonate. Pediatr Infect Dis J 1987; 6(8): 758-759.

7. Blinkhorn RJ, Adelstein D, Spagnuolo PJ. Emergence of a new opportunistic pathogen, C. lusitaniae. J Clin Microbiol 1989; 27(2): 236-240.

8. Peyron F, Favel A, Michel Nguyen A, Gilly M, Regii P, Balmstrom A. Improved detection of amphoterisin B-resistant isolates of C.lusitaniae by E test. J Clin Microbiol 2001; 39(1): 339-342.

9. Kollia K, Arabatzis M, Kostoula O, Kostourou A, Velegraki A, Belessiotou E, et al. Clavispora (Candida) lusitaniae susceptibility profiles and genetic diversity in three tertiary hospitals (19982001). Int J Antimicrob Agents 2003; 22(4): 458460.

10. Viviani MA, Tortorano AM, Piazzo T, Bassi F, Grioni A, Langer M. Candidasis surveillance in intensive care unit patients. Bull Soc Fr Mycol Med 1986; 15: 121-124. 